\title{
VISCOSIMETRIC ASSAY OF ENDOGLUCANASE ACTIVITY IN ENZIME FODDER ADDITIVES
}

\section{A.A. KOMAROV, L.Ya. TELISHEVSKAYA, A.A. SARKHANOVA, L.V. VASIL'EVA, E.G. TITOVA, A.N. PANIN}

All-Russian State Center for Quality and Standartization of Veterinary Drugs and Feed, Federal Agency of Scientific Organizations, 5, Zvenigorodskoe sh., Moscow, 123022 Russia, e-mail 1.telishi@mail.ru Received September 3, 2015

\begin{abstract}
Worldwide a large number of enzymes, including those with endo- $\beta$-glucanase activity are produced by different companies as fodder additives. In Russia, there is no uniform method for endo- $\beta$-glucanase activity analysis that causes difficulties in assessing quality of the enzyme preparations. The aim of the study was to develop such uniform method. In this, we optimized a viscometric determination based on change of the relative viscosity of a substrate mixed with enzyme preparation using Ostwald capillary viscometer. The following regime has been accepted: the diameter of the capillary is $0.73 \mathrm{~mm}$; the temperature of hydrolysis is $30^{\circ} \mathrm{C}$; the solvent is the acetate buffer $(\mathrm{pH} 4.7)$; time of incubation is 5, 10, 15 min in accordance with the kinetics of the enzymatic reaction; and $\beta$ glucane $(0.4 \%)$ was used as substrate. The carboxymethyl cellulose is shown not to be relevant so far as it gives results incomparable with those obtained with $\beta$-glucane due to estimation of the cellulase but not the $\beta$-glucanase activity, that does not correspond to the objectives of forage production. The unit used in the developed method is the amount of enzyme which increases the relative substrate flow rate in $1 \mathrm{~min}^{-1}$ under standard conditions of hydrolysis. The measurement of accuracy of the method was carried out according to GOST R ISO 5725-2002 (the state standards). In this, 5 certified samples with different activity were prepared from a commercial sample of $\beta$-glucanase (SigmaAldrich, USA) with known activity (GLA/g). The activity of the standard was expressed in GLA/g as glucose equivalents corresponding to the amount of enzyme which acts on $\beta$-glucane, releasing 1 $\mu \mathrm{mol}$ of sugars in terms of glucose. Certified samples were analyzed under intermediate precision conditions with three factors changed (i.e., operator, matrix, reagents). The matrices were mineral fillers, the calcium carbonate and zeolite. To calculate the accuracy of the method the viscosity of certified samples was expressed in GLA units using the calibration curves. Expanded uncertainty of measurements ranged within $10-22 \%$ for the coverage factor $\mathrm{k}=2$.
\end{abstract}

Keywords: endoglucanase activity, non-starch polysaccharides, hemicellulose, viscosity, viscosimetry, $\beta$-glucane, carboxymethyl cellulose, matrix, intermediate precision, expanded uncertainty

Currently, a variety of enzymatic additives used to reduce content of fodder antinutrients have been developed for animal husbandry. Xylanase, glucanase, cellulose, the cytolytic cleaving enzymes, are added in the fodder for monogastric animals, including poultry in which non-starch core polysaccharides (cellulose, hemicellulose, lignin, pectin) are poorly digestable. A high content of soluble non-starch polysaccharides, such as hemicelluloses (xylans and glucans), results in fodder high viscosity, when using fresh harvest or in drought years, especially. Widespread practical use of cellulase and hemicellulase preparations in recent years is due to the maize substitution with cereals (barley, rye, wheat, oats, triticale, and meal and cake) in diets, and to an increase in the levels of non-starch polysaccharides in fodder. Foreign manufacturers estimated such additive activity using their own methods (Rovabio, BASF, Biovet AD, Kemin). This causes difficulties, as it is not possible to compare the effects of different enzyme feed additives with one other and versus the products for similar purposes declared by manufacturers [1-3].

In 2012, the interstate standards regulating enzymatic feed additive $\beta$ - 
xylanase and cellulase activity were developed in Russia (GOST 31488, GOST 31662) and starting from June 1, 2013, a national standard (GOST R 549052012) was enacted to describe a unified method of endoglucanase activity assay. However, more and more foreign companies and laboratories are recently switching to the endo- $\beta$-glucanase activity measurement because of the requirements of feed production.

It is endoglucanases that make it possible to reduce chyme viscosity in the course of passage through the gastrointestinal tract of monogastric animals, such as pigs and poultry $[4,5]$, as well as young cattle and small ruminants. The ability of enzymes added to fodder to cleave carbohydrate polymers into smaller fragments makes it possible to solve the problem of improving digestibility of non-starch polysaccharides such as cellulose and hemicellulose which are actually not cleaved by animal glycolytic enzymes. Enzymatic additives allow the wider use of grain diets as an energy source for poultry and pigs [6, 7]. There are over 60 enzyme preparations with different activity that are considered authorized [8-11]. However, unified methods of estimating and comparing these preparations have not been set which results in a problem for the control of their production and use [12].

The methods described can be divided into two groups, colorimetry and viscosimetry [13]. Viscometry provides direct activity measurement as based on determining the rate of a polysaccharide substrate viscosity decrease. Colorimetric methods are indirect, and based on enzyme hydrolysis of stained substrates (polysaccharides) with chromophore elimination and estimation of thus developing color. The results of colorimetric assay have to be assessed in specific optical density (OD) units or expressed in the units adopted for measuring endoglucanase activity (GLA) as glucose equivalents with standard enzyme. However, as there is no unified standard endoglucanase activity assay method, declared activity of standard enzyme depends on the manufacturer (including the method for the measurement of enzyme activity and specificity). Therefore, in our opinion, viscometry, of the two approaches, is the more promising for the standardization of endoglucanase activity research methods and for obtaining comparable results, and is used in a number of laboratories [14-16]. The activity unit used in viscosimetric studies is the amount of enzyme which increases the relative substrate flow rate equal to $1 \mathrm{~min}^{-1}$ under standard $\beta$-glucan hydrolysis conditions.

Thus, there have been no uniform methods for animal endo- $\beta$-glucanase activity analysis in Russia which caused difficulties in certification and regulations for use of these feed additives. We first optimized the viscometric assay of endoglucanase activity based on the assessment of substrate relative viscosity measurement using a capillary viscometer.

Our purpose was to develop a method which allows to standardize the measurement of endo- $\beta$-glucanase activity in enzyme preparations used as additives to reduce feed antinutrient content.

Technique description. Viscosity of samples was analyzed using a viscosimetric assay method [17] with our modification. Relative viscosity of substrates was measured using an Ostwald capillary viscometer with capillary diameter of $0.73 \mathrm{~mm}$ according to liquid outflow rate (outflow viscometer) as compared with the solvent (acetate buffer, $\mathrm{pH} 4.7$ ) at $30{ }^{\circ} \mathrm{C}$. The solvent was poured into viscometer, incubated at $30{ }^{\circ} \mathrm{C}$ for $5 \mathrm{~min}$, and passed 3 to 5 times sequentially to estimate the average flow time $\left(t_{p}\right)$. Further, viscometer was emptied, $8 \mathrm{~cm}^{3}$ of substrate and $1 \mathrm{~cm}^{3}$ of buffer solution were added with a pipette (the volume is viscometer-specific, $9 \mathrm{~cm}^{3}$ in our case), the mixture was incubated for $5 \mathrm{~min}$ at $30{ }^{\circ} \mathrm{C}$ and passed 3-5 times to indicate start outflow time $\tau_{0}$. Viscometer was 
emptied again, washed thoroughly, and dried, then $8 \mathrm{~cm}^{3}$ of substrate were added, incubated at $30{ }^{\circ} \mathrm{C}$ for $5-7 \mathrm{~min}$, then $1 \mathrm{~cm}^{3}$ of pre-heated $\left(30{ }^{\circ} \mathrm{C}\right)$ enzyme solution (sample) was added. The contents of viscometer was mixed by air bubbling. Time of substrate-enzyme mixture outflow $\left(t_{i}\right)$ was registered $\left(\tau_{i}\right)$ for 5 , 10, and 15 min of incubation, in accordance with the kinetics of the enzymatic reaction (M.L. Rabinovich, A.A. Klesov, I.V. Beresin, 1977).

Relative viscosity of incubation mixture was calculated for each incubation period $\left(\tau_{i}\right.$, including $\left.\tau_{0}\right)$ using the following formula:

$$
\eta_{i}=\frac{t_{i}-t_{p}}{t_{p}},
$$

where $\eta_{i}$ is relative viscosity in the $\tau_{i}$ incubation period; $t_{i}$ is the time of incubation mixture outflow in each incubation period, sec; $t_{p}$ is the time of solvent outflow, sec. Based on the resulting values, relative flow was calculated as the reciprocal relative viscosity $\left(1 / \eta_{i}=b_{i}\right)$. interval:

The change in relative viscosity per minute was estimated for each time

$$
A_{i}=\left(b_{i}-b_{0}\right) / \tau_{i}, \min ^{-1}=\Delta b / \tau, \min ^{-1},
$$

where $b_{0}$ is the baseline relative viscosity at $\tau_{0}$.

Endo- $\beta$-glucanase activity (units/g) was calculated as follows:

$$
\text { EndoGLA }=A / C \text {, }
$$

where $A$ is relative viscosity change per min; C is amount of enzyme in reaction mixture, g. $A$ was calculated as the $A_{i}$ arithmetic mean for each incubation period $\left(\tau_{i}\right)$ using formula $(2)$.

A series of standard dilutions (standard solutions) were prepared for which the viscosity (fluidity) of the hydrolyzed substrate were estimated after 10 min incubation by outflow time.

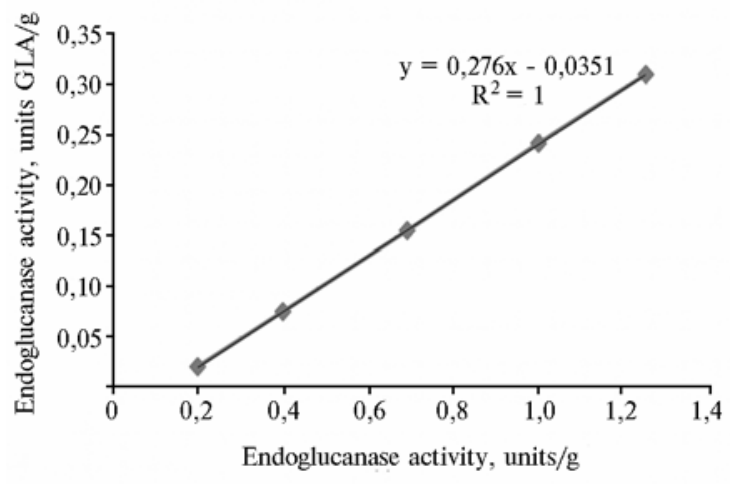

Example of calibration curve to convert viscometry in GLA units in the assay of endo- $\beta$-glucanase activity based on substrate fluidity changes.

To express endo- $\beta$-glucanase activity in GLA units, calibration curves were constructed in each assay series (Fig.). $\beta$-Glucanase (Trichoderma longibrachiatum) of 3100 units/g (units GLA) activity (Sigma-Aldrich, USA) was used as standard.

The viscosimetric results expressed in units/g, were converted to GLA units.

Method accuracy was assessed by analyzing certified samples with different $\beta$-glucanase levels under interlaboratory precision with the following variable factors: operator (№ 1 and № 2), reagent kit (№ 1 and № 2), and matrix. Calcium carbonate (CP, Russia) and zeolite (Nov' NPF, Novosibirsk), the mineral fillers, were the matrices. Each certified sample activity was calculated as standard (enzyme) concentration in certified mixture containing mineral filler. Thus, 5 samples of $93,310,620,1033$, and 1550 units GLA/g activity were prepared for each filler, and 8 experiments (total of 40 measurements) were performed considering the three factors for each activity (Table 1).

The 0.1 to $0.5 \% \beta$-glucan and carboxymethyl cellulose (CMC) solutions in acetate buffer $(0.1 \mathrm{M}, \mathrm{pH} 4.7)$ were tested as substrates.

Data processing for each certified sample, with regard to individual test 
for 8 variants, included calculation of mean values and mean value dispersion $\mathrm{S}^{2}$. Based on the resulting values, relative expanded uncertainty $(\%)$, repeatability limit $(\%)$, and relative uncertainty accuracy indices $(\%)$ were calculated.

1. Experimental scheme to assess the accuracy of the method proposed to standardize viscometric endo- $\beta$-glucanase activity assay

\begin{tabular}{|c|c|c|c|}
\hline \multirow{2}{*}{$\begin{array}{l}\text { Experiment } \\
\text { No. }\end{array}$} & \multicolumn{3}{|c|}{ Variable factor } \\
\hline & matrix & reagent kit & operator \\
\hline 1 & Calcium carbonate & 1 & 1 \\
\hline 2 & Calcium carbonate & 2 & 2 \\
\hline 3 & Zeolite & 2 & 2 \\
\hline 4 & Calcium carbonate & 2 & 1 \\
\hline 5 & Zeolite & 1 & 2 \\
\hline 6 & Calcium carbonate & 1 & 2 \\
\hline 7 & Zeolite & 1 & 1 \\
\hline 8 & Zeolite & 2 & 1 \\
\hline
\end{tabular}

When determining the optimum substrate concentrations, attention was paid to the time of initial solution outflow compared to the solvent. With the solvent (buffer solution) flow rate of 26-30 sec, the outflow rate of baseline solutions of tested concentrations was from $40 \mathrm{sec}$ (for $0.1 \% \mathrm{CMC}$ ) to $114 \mathrm{sec}$ (for $0.5 \% \beta$-glucan). The outflow time of $60-80$ seconds can be regarded optimal. At higher rates (as for $0.1 \% \mathrm{CMC}$ ), a reduced viscosity of the mixture as a result of enzyme activity may cause a reduction in its outflow time to that of the solvent. As the outflow time increases to $80 \mathrm{sec}$, the controlled period of substrateenzyme contact decreases.

Accordingly, we chose $0.4 \%$ for $\beta$-glucan and $0.2 \%$ for $\mathrm{CMC}$ as the optimal substrate concentrations to be further used in this study.

Testing optimal concentrations of various substrates showed a mismatch between the final results for viscosity, which is associated with enzyme specificity. Endo- $\beta$-glucanase cleaves 1,3- and 1,4- $\beta$-glycosidic bonds in glucose residue chain, and hydrolyzes both glucan (hemicellulose) and cellulose for these bonds. For this reason, some authors use these substrates as interchangeable ones [17, 18 , and the $\beta$-glucanase and cellulase enzyme names as synonyms. Both substances are glucose polymers in which monomers are $\beta-1.3$ and $\beta-1.4$ bonds linked. They belong to non-starch polysaccharides and antinutrients as not cleaved by enzymes in animal gastrointestinal tract and preventing assimilation of other fodder nutrients.

However, these compounds differ both in their composition and physical and chemical properties. Glucans are hemicelluloses with a molecular weight up to 50,000 Da and a branched structure. They are soluble in weak acids and alkalis, and are contained in barley, rye, and wheat seeds. Cellulose is insoluble linear glucose polymers with a molecular weight from 50,000 to 1,800,000 Da. They are not soluble in acids and alkalis, and are part of cereal cell walls. It is hemicelluloses (xylans and glucans) that determine chyme viscosity and cause major problems of digestion and assimilation of fodder nutrients.

To compare substrate effects on the final assay results, the Hostazim (Biovet, Bulgaria) viscometric endoglucanase activity was assayed with two substrates. It was found that sample viscosity was $12125 \pm 1819 \mathrm{U} / \mathrm{g}$ for $\beta$-glucan and $56500 \pm 475 \mathrm{U} / \mathrm{g}$ for CMC.

$\beta$-Glucan makes it possible to detect $\beta$-glucanase activity, while CMC provides data on cellulase (more precisely, on CM-cellulase) activity, which may vary considerably for the same sample. In this case, the latter was 4.5 times higher which was apparently determined by the specificity of the enzyme wherein cellulase activity predominates, and depends on the properties of the 
enzyme producing fungus.

In this connection, we used $\beta$-glucan only as a substrate in subsequent tests and performed studies with the three factors - operator, matrix (calcium carbonate and zeolite), and reagent kit. Based on the findings, we estimated the indices of method accuracy in accordance with domestic GOST R ISO 57252002 [19] and RMG 61-2010 [20] (Table 2).

2. Calculated parameters for the accuracy of the method proposed to standardize viscometric endo- $\beta$-glucanase activity assay

\begin{tabular}{l|r|r|r|r|r}
\hline \multirow{2}{*}{ Parameter } & \multicolumn{5}{c}{ Standard sample activity, units GLA/g } \\
\cline { 2 - 6 } & 93 & 310 & 620 & 1033 & 1550 \\
\hline Relative expanded uncertainty for cover- & & & & & 11.3 \\
age factor k $=2, \%$ & 22.1 & 11.3 & 9.6 & 12.2 & 8.0 \\
Repeatability limit, $\%$ & 12.8 & 7.3 & 13.3 & 2.6 & 3.4 \\
Relative uncertainty accuracy index, \% & 4.6 & 3.2 & 3.2 & 3.4 \\
\hline
\end{tabular}

The results allow to accept the range of endoglucanase activity of 93$1550 \mathrm{U}$ GLA/g, as converted to glucanase equivalent, when using viscometric method. Best results may be obtained in the range of 310-1550 units GLA/g which corresponds to $1240-6200 \mathrm{U} / \mathrm{g}$ commonly used in viscometric method, with an expanded uncertainty of $10-12 \%$.

Thus, the assessment of fodder additive endo- $\beta$-glucanase activity based on a reduced relative viscosity (or increased relative fluidity) of enzyme-substrate mixture was optimized. A capillary viscometer of $0.73 \mathrm{~mm}$ diameter is used. The temperature of hydrolysis is $30^{\circ} \mathrm{C}$, and the acetate buffer $(\mathrm{pH} 4.7)$ serves as solvent which corresponds to the optimal enzyme activity when incubating for 5 , 10 , and $15 \mathrm{~min}$. Of the two possible substrates, $\beta$-glucan and carboxymethyl cellulose, the $\beta$-glucan $0.4 \%$ solution was preferable as mostly appropriate for the specific enzyme activity. The $\beta$-glucanase activity units can be converted to glucose equivalents (units GLA) using calibration curves with a standard enzyme of known activity. Parameters of the accuracy of the developed method were assessed. Expanded uncertainty of measurements ranges within 10-22 \% (10-12\%) for the coverage factor $\mathrm{k}=2$.

\section{REFEREN C ES}

1. Grishutin S.G., D zedzyulya E.I., Kondrat'eva E.G., Zorov I.N., Sinit s y n a O.A., S i n its y n A.P. Sravnitel'noe testirovanie kommercheskikh fermentnykh preparatov dlya kormoproizvodstva [Comparative estimation of commercial enzymes for feed production (in Russ.). Available http://biovet-ferment. ru/index.php?id=50. Accessed 25 March 2016].

2. Komarov A.A., Telishevskaya L.Ya., Shevchenko A.A., Vasil'eva L.V., P a $n$ i n A.N. Vetkorm, 2013, 3: 8-10 (in Russ.).

3. Cho t M. Enzymes for the feed industry: past, present and future. Worlds Poult. Sci. J., 2006, 62: 5-15 (doi: 10.1079/WPS200480).

4. Zhang Z., Marquardt R.R., Gue n te r W. Evaluating the efficacy of enzyme preparations and predicting the performance of Leghorn shicks fed rye-based diets with a dietary viscosite assay. Poultry Sci., 2000, 79: 1158-1167 (doi: 10.1093/ps/79.8.1158).

5. Ge ra ert P.-A., Pa la is F., Gre nie r S., J a k ob S. Dietary carbohydrates: a review of their physicochemical properties and digestibility in poultry and swine. Proc. Eastern Nutrition Conference (May 10-11, 2005). Canada, Ontario, 2005: 1-18.

6. Olukosi O.A., Cowies on A.J., Ade ola O. Energy utilization and growth of broilers receiving diets supplemented with enzymes containing carbohydrase or phytase activity individually or in combination. Br. J. Nutr., 2008, 99(3): 682-690.

7. Carvalho J.C.C., Rios R.L., Lima E.M.C., Bertechini A.G., Piracés F., Sorbara J.O.B. Differences in corn energy with the use of $\alpha$-amylase and $\beta$-glucanase for broilers in various production stages. Proc. Poultry Science Association Annual Meeting. Canada, Ontario, 2008: 67.

8. Rovabio ${ }^{T M}$ Eksel' $^{\prime} A P($ http://agrovetspb.ru).

9. Natugrein TS. Natugrein TS.mht [Natugrain TS. Available http://kormovet.com. No date (in Russ.)]. 
10. Hostasim (Biovet AD, Huvefarma AD, Bulgaria). Available http://www.webvidal.ru/Veterinary/2011/LP_100988.htm. No date (in Russ.)]

11. Kemzyme. Kemin products. Available https://www.kemin.com/en/middle-east/products/kemzyme/kemzyme-range/. Accessed March 25, 2016.

12. $\mathrm{Z}$ i e b a 1 R. Pitfalls and challenges for the official control of enzymes in feed. In: Antimicrobial growth promoters. Wageningen Academic Publishers, the Netherlands, 2006: 249-254.

13. Telishevskaya L., Sarkhanova A., Vasil'eva L., Khvatova D., Titova E. Kombikorma, 2015, 9: 103-104 (in Russ.).

14. Enge le n A.J., va n d e r H e e ft F.C.., R a n d s d o r p P.H.G. Viscometric determination of beta-glucanase and endoxylanase activity in feed. Journal of AOAC International, 1996, 79: 5.

15. M c Cle a ry B.V. Analysis of feed enzymes. In: Enzymes in farm nutrition. M. Bedford, G. Partrige (eds.). CAB International, 2001: 85-107.

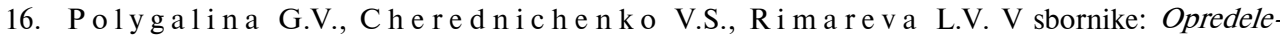
nie aktivnosti fermentov [In: Enzyme assay (in Russ.)]. Moscow, 2003: 180-181.

17. Vlasenko E.Yu., Ryan A.I., Shoemaker Ch.F., Shoemaker Sh.P. The use of capillary viscometry, reducing end-group analysis, and size exclusion chromatography combined with multiangle laser light scattering to characterize endo-1,4- $\beta$-D-glucanases on carboxymethylcellulose: a comparative evaluation of the three methods. Enzyme and Microbial Technology, 1998, 23: 350-359.

18. An kudi mova N.V. Biokhimicheskie i fiziko-khimicheskie svoistva klyuchevoi topoliticheskoi endoglyukanazy tsellyulaznogo kompleksa Chaetomium cellulolyticum. Kand. dis. [Biochemical, physical and chemical characterization of the key topolytic endoglucanase of the Chaetomium cellulolyticum cellulase complex. PhD Thesis (in Russ.)]. Moscow, 2000.

19. GOST R ISO 5725-2002 [Accuracy (correctness and precision) of mesuarements and obtained data. State Standard GOST R ISO 5725-2002 (in Russ.)]. Moscow, 2002.

20. RMG 61-2010 [RMG 61-2010. Recommendations on Interstate Standardization. State system for ensuring the uniformity of measurements. Indicators of correctness, accuracy, precision of the quantitative chemical analysis techniques. Assessment methods (enacted by the Order of the Rosstandart of December 13, 2011, No 1064st (in Russ.)]. Moscow, 2013. 